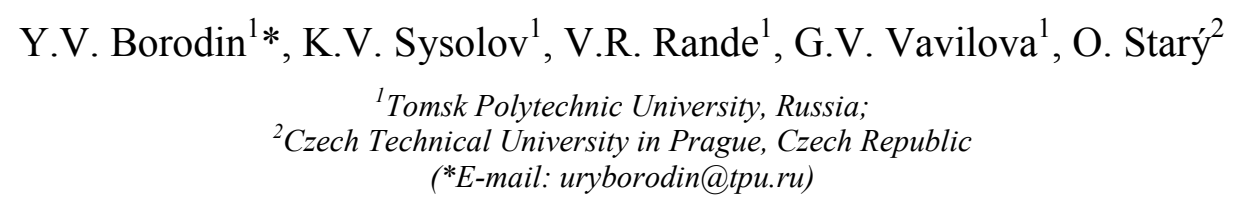

\title{
Spectroscopy of nanoscale crystalline structural elements
}

\begin{abstract}
The study of structural elements, nanoparticles, microblocks and other nanoscale objects was an important part of the study of crystals non-equilibrium properties. The behavior of nanoscale structures allows us to judge the dynamics of the crystal lattice during doping, deformation, and interactions with radiation. Along with $x$-ray and electron microscopic studies, optical methods for determining the size of nanoscale objects, the energy of their electrons, and the symmetry of electronic States are increasingly being used. Among nanoscale objects, proton-separated structural elements (PSE) attract special attention in connection with the development of crystal structure block-hierarchical (BH) model. In this paper, we consider the possibility of calculating the size of PSE crystals in a model of quantum-dimensional structures. According to this model except values of the crystal potential in PSE, you should consider the area of high electron density, the existence of which is beyond the scope of conventional theory. Experimental data allow us to determine the position of this zone as localized around the atomic core of the PSE. Note that the atomic backbone generally coincides with the unit cell, that is, it consists of the same number of atoms and has the same point symmetry group.
\end{abstract}

Keywords: nanoparticles, microblocks, nanoscale cstructural elemtnts, proton-separated structural elements.

\section{Introduction}

The solution of the Schrodinger equation is quite difficult to obtain for arbitrary functions of the crystal potential and the potential of the zone of increased electron density $U(r)$ and $V(r)$. We can use the spherical approximation and assume that the function $V(r)$ is spherically symmetric inside the sphere of radius $R$ surrounding the atoms. A similar approach takes place in the theory of a solid body as the method of attached plane waves (APW) [1]. Within a unit cell, the eigenfunction $\psi(k, r)$ corresponding to the energy $E(k)$ can be represented as a series

$$
\psi(k, r)=\sum_{l=0}^{\infty} \sum_{m=-l}^{l} C_{l m}(k) \cdot Y_{l m l}(\theta, \varphi) \cdot R_{l}(E, r) \cdot \eta(R-r)+\sum_{j} b_{j}(k) \cdot \exp \left[i \cdot k_{j} \cdot r\right] \cdot \eta(r-R),
$$

where $r, \theta, \varphi$ are the polar coordinates of the radius vector $r$ relative to the center of the PSE, $\eta(x)$ is a step function

$$
\eta(x)=\left\{\begin{array}{l}
0, x<0 \\
1, x>0
\end{array}\right.
$$

The main difference between the approach considered in this paper and the PPV is that there is no translational symmetry of quantum-dimensional structures [2-9]. We have the standard problem of an atom located in a spherically symmetric quantum well [1]. The wave function will take the form: $\psi_{l m}=R_{l}(r) \cdot Y_{l m}(\theta, \varphi)$. The Schrodinger equation describing the stationary States of an electron with energy $E$ has the form

$$
\frac{\hbar^{2}}{2 m} \cdot \Delta \psi+(E-V(r)) \cdot \psi=0
$$

The equation for the radial component will look like this:

$$
R_{l}^{\prime \prime}+\frac{2}{r} \cdot R_{l}+\left[k^{2}-\frac{l(l+1)}{r^{2}}\right] \cdot R_{l}=0
$$

where $k^{2}=\frac{2 m E}{\hbar^{2}}$. 


\section{The absorption spectra of the structural elements}

The model under consideration, according to experimental data, assumes the value of the potential of the zone of increased electron density, which is sufficiently large in comparison with the crystal potential. Equation (1) is written in the infinite potential approximation. The function $R_{l}(E, r)$ can be defined by numerically integrating a differential equation in the domain under consideration for a series of values $E$ and $l$. Using substitution, equation (1) can be reduced to the form

$$
\chi_{k}^{\prime \prime}+\frac{2(l+1)}{r} \chi_{l}^{\prime}+k^{2} \chi_{l}=0 .
$$

Differentiating equation (2) by $r$, we get

$$
\chi_{l}^{\prime \prime \prime}+\frac{2(l+1)}{r} \chi_{l}^{\prime \prime}+\left[k^{2}-\frac{2(l-1)}{r^{2}}\right] \chi_{l}^{\prime}=0 .
$$

By substituting $\chi_{l}^{\prime}=r \chi_{l+1}(3)$, it is reduced to the form

$$
\chi_{l+1}^{\prime \prime}+\frac{2(l+2)}{r} \chi_{l+1}^{\prime}+k^{2} \chi_{l+1}=0
$$

coincides with the one that the function must satisfy $\chi_{l+1}$. Thus, successive functions are related by the relation

$$
\chi_{l+1}=\frac{1}{r} \chi_{l}^{\prime} ; \chi_{l}=\left(\frac{1}{r} \frac{d}{d r}\right)^{l} \chi_{0} .
$$

Finally we find the following expression for radial functions

$$
R_{l}=2 k \cdot j_{l}(r),
$$

where $j(r)$ are spherical Bessel functions.

The electron energy En.l is defined by the expression under the condition

$$
J_{l+1 / 2}(k R)=0 .
$$

Numerically solving equation (4), a set of $k$ values is obtained and the band spectrum is determined. The final expression for the electron energy has the form

$$
E_{n, l}=\frac{\hbar^{2}}{2 m R^{2}} x_{n, l}^{2}
$$

where $x_{n, l}$ are the constants found from equation (4) that characterize the electron energy levels in a crystal with indices $n, l[10]$.

Having a band spectrum, we find the allowed transitions between energy levels. Let's define the selection rules for absorption in the crystal. The symmetry of the crystal is important. When calculating the selection rules for a specific crystalline substance, it is necessary to determine the point symmetry group $G$ of the unit cell (the same symmetry group will be inherent in the PSE). We find the decomposition of the representation of this group by irreducible representations:

$$
T=\sum_{v} a_{v} T^{(v)}
$$

The probability of a transition between energy States and is determined by the square of the matrix element $\psi_{i} H_{\mathrm{vz}} \psi_{0}$ of the $H_{\mathrm{vz}}$ operator of the interaction of radiation with matter. If executed

$$
\psi_{i} H_{\mathrm{vz}} \psi_{0}=0
$$

then the system cannot go from state $\psi_{i}$ to $\psi_{j}$ by emitting or absorbing a quantum of light. On the other hand, the functions $\psi_{i}$ and $\psi_{j}$ can be considered as elements of some linear spaces $L_{i}$ and $L_{j}$, which are transformed by representations $T_{i}$ and $T_{j}$ of the group $G$ of the point symmetry of the crystal. As a result, the left side of equation (5) is transformed by the action of the elements $G$ in the representation $\tilde{T}_{i} \times V \times T_{j}$. Here the $H_{\mathrm{VZ}}$ operator is transformed by the vector representation $V$ of group G. If the representation $\tilde{T}_{i} \times V \times T_{j}$ does not contain a single representation, then the matrix element in (5) is zero and the transition $\psi_{i} \rightarrow \psi_{j}$ in the considered approximation is forbidden. The representation $\tilde{T}_{i} \times V \times T_{j}$ must contain a single 
representation, and this requires that the product $V \times T_{j}$ contains at least one representation included in $T_{i}$ [11]. Then the selection rules in the crystal for light absorption PSE and PSE blocks are reduced to the following criterion

$$
V \times T_{j} \cap T_{i} \neq 0 .
$$

Taking into account the selection rules, we get a finite number of absorption lines in the crystal on the PSE, and the number of electrons at the level with the index $l$ is equal to $(2 l+1) 2$. You can also solve the inverse problem, that is, calculate the size of the PSE from a given absorption spectrum.

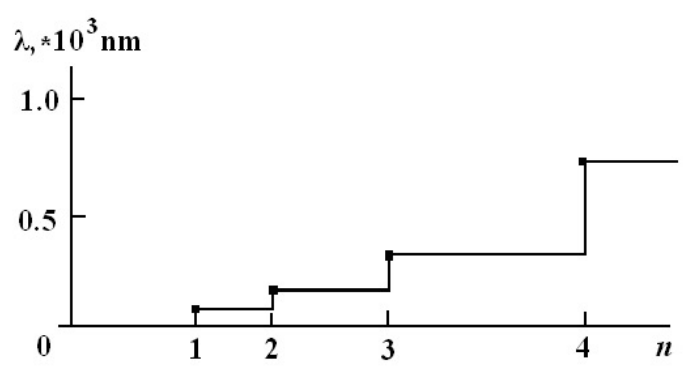

Figure 1. Dependence of the absorption wavelength of PSE blocks on the step of a series of numbers in the Fibonacci series

This approach can be applied in some approximation to PSE blocks. There will be a difference in the determination of the electronic density of the PSE block. It can be assumed that in this process, the determining value is the conduction electrons of the crystal. Changes in the structure of a block's potential are made by its point symmetry relative to lower-order blocks. As can be seen from the expression for determining the proper energy of an electron in a PSE, its energy spectrum depends on the size. Given the correspondence of the PSE size to a number of Fibonacci numbers, it is possible to predict the absorption spectrum of PSE blocks based on the specified PSE characteristics. Figure 1 shows the dependence of the absorption wavelength of a crystal on a structural element on the number of the Fibonacci series. The calculation method discussed above provides sufficient accuracy for qualitative consideration of the spectrum.

The decrease of the electron density in the zones surrounding the PSE blocks is experimentally established, and the block structure is modulated in the crystal space with an increase in their size. This is observed until the value of the potential barrier of the zone of increased electron density of the next block becomes equal to the crystal potential considered in the solid state theory. This imposes a condition of finiteness of the modulation order and its critical value is different for different materials due to the difference in the overall potential picture of the crystal lattice.

In the method of calculating the parameters of the PSE, significant approximations were made: the oneelectron theory was used, which replaced the interaction of the crystal's electrons with a certain effective field, the zone of increased electron density had a spherical symmetry relative to the center of the PSE, and the value of the potential barrier rushed to infinity. Despite the above-mentioned approximations, there is a sufficient agreement between the calculated PSE sizes and experimental data from $X$-ray diffraction and absorption spectra at the f-centers of crystal color [12]. In this case, the F-center performed the function of the PSE, and the feature of localization of an electron from an anionic vacancy on a cationic environment satisfies the formalism of the considered quantum-dimensional model of the crystal. The sizes of F-centers for a number of alkali metal halides are estimated using known absorption lines. The considered model of the F-center likens it to a block of a crystal. Satisfactory results are obtained when the potential of the F-center is approximated by the rectangular well function. The choice of F-centers as the PSE model is quite justified, since the crystals of alkali metal halides have a high symmetry, and therefore, the distribution of the uncompensated positive charge of cations surrounding the anionic vacancy is close to spherical.

\section{Oscillatory Raman spectra of structural elements}

The method of studying the quantum-dimensional structure of a material based on light absorption is generally simple. Solving the absorption problem, it is possible to obtain its band spectrum and other characteristics obtained in the previous section. However, this method does not allow us to study the dynamics of the lattice, both translational and quantum-dimensional, modulated, considered by the model in this work. 
The method associated with Raman scattering of light on the microblocks we are considering actually displays the properties of a modulated low-dimensional lattice and allows us to calculate its vibrational States. Here, the symmetry of the crystal plays a crucial role and determines the matrix elements that are different from zero.

We solve the vibrational problem and assume that the PSE vibrational movements occur in the crystal space, similar to the vibrations of atoms in the translational model of a crystal. The vibrational motion of the atomic core is considered as a collective vibrational process. Formally, this can be represented as a system of 3-dimensional oscillating oscillators with dimensions equal to the PSE and some effective masses. It is quite difficult to solve such a 3-dimensional case of the problem, since, according to the quantum-dimensional model, the distances between oscillating oscillators are not the same. It is necessary to simplify the problem to the one-dimensional case, provided that the process of linearization of the crystal lattice preserves some of its properties unchanged and does not significantly affect the values of those characteristics that need to be studied in this work. The problem is reduced to the study of the characteristics of a one-dimensional aperiodic chain of oscillating oscillators. The chain through some transformations can be described by the Fibonacci sequence, which is a special case of aperiodic sequences. Then the one-dimensional Fibonacci chain will preserve some properties of the crystal in 2-and 3-dimensional lattices [13]. This may be the property of selfsimilarity, which is a fairly important characteristic of any Fibonacci sequences [1].

Let all PSE in a linear chain oscillate near the equilibrium position with an offset $U\left(\begin{array}{l}l \\ \alpha\end{array}\right)$. Here $\alpha$ is the PSE number in the chain, and $l$ is the coordinate of the center of each PSE. Then the Hamilton and Lagrange functions of the system in the harmonic approximation have the form

$$
\begin{aligned}
& H=T+\Phi=\frac{1}{2} \sum_{l, \alpha} m_{\alpha}\left[\dot{u}\left(\begin{array}{l}
l \\
\alpha
\end{array}\right)\right]^{2}+\frac{1}{2} \sum_{\substack{l, l^{\prime} \\
\alpha, \alpha^{\prime}}} \Phi\left(\begin{array}{l}
l l^{\prime} \\
\alpha \alpha^{\prime}
\end{array}\right) \cdot u\left(\begin{array}{l}
l \\
\alpha
\end{array}\right) \cdot u\left(\begin{array}{l}
l^{\prime} \\
\alpha^{\prime}
\end{array}\right) ; \\
& L=T-\Phi=\frac{1}{2} \sum_{l, \alpha} m_{\alpha}\left[\dot{u}\left(\begin{array}{l}
l \\
\alpha
\end{array}\right)\right]^{2}-\frac{1}{2} \sum_{\substack{l, \alpha \\
l^{\prime}, \alpha^{\prime}}} \Phi\left(\begin{array}{l}
l l^{\prime} \\
\alpha \alpha^{\prime}
\end{array}\right) \cdot u\left(\begin{array}{l}
l \\
\alpha
\end{array}\right) \cdot u\left(\begin{array}{l}
l^{\prime} \\
\alpha^{\prime}
\end{array}\right) .
\end{aligned}
$$

Here $m_{\alpha}$ - the effective mass of the PSE with the number $\alpha, \Phi\left(\begin{array}{l}l l^{\prime} \\ \alpha \alpha^{\prime}\end{array}\right)$ - the coefficients of the second order in the decomposition of potential energy by deviations of the PSE.

The equations of motion respectively have the form

$$
m_{\alpha} \ddot{u}\left(\begin{array}{l}
l \\
\alpha
\end{array}\right)+\sum_{l^{\prime} \alpha^{\prime}} \Phi\left(\begin{array}{l}
l l^{\prime} \\
\alpha \alpha^{\prime}
\end{array}\right) \cdot u\left(\begin{array}{l}
l \\
\alpha
\end{array}\right)=0 .
$$

Solutions of equation (6) have the form

$$
u\left(\begin{array}{l}
l \\
\alpha
\end{array}\right)=u^{0}\left(\begin{array}{l}
l \\
\alpha
\end{array}\right) \cdot e^{-i w t}
$$

After substituting (7) in (6), we get

$$
\sum_{l \alpha}\left[\Phi\left(\begin{array}{l}
l l^{\prime} \\
\alpha \alpha^{\prime}
\end{array}\right)-w^{2} m_{\alpha^{\prime}} \delta_{\alpha \alpha^{\prime}} \delta_{l l^{\prime}}\right] \cdot u^{0}\left(\begin{array}{l}
l^{\prime} \\
\alpha^{\prime}
\end{array}\right)=0 .
$$

The solvability condition of the system ( 8 ) is that the determinant is equal to zero

$$
\left(\Phi\left(\begin{array}{l}
l l^{\prime} \\
\alpha \alpha^{\prime}
\end{array}\right)-w^{2} m_{\alpha^{\prime}} \delta_{\alpha \alpha^{\prime}}(=0 .\right.
$$

Equation (9) is an algebraic equation of degree $N$ with respect to $w^{2}$. Denote the eigenvectors of the system (8) $l\left(\alpha(j)\right.$ and the corresponding eigenvalues $w^{2}(j)$. Making the transition to normal coordinates

$$
u_{\alpha}\left(\begin{array}{l}
l \\
\alpha
\end{array}\right)=\sum_{j} l_{\alpha}(\alpha(j) \cdot Q(j) \text {. }
$$


The Hamilton function takes the following form

$$
H=\frac{1}{2} \sum_{j}\left(\dot{Q} *(j) \cdot \dot{Q}(j)+w^{2}(j) \cdot Q *(j) \cdot Q(j)\right) .
$$

From here we get the equation of motion for the PSE

$$
\ddot{Q}(j)+w^{2}(j) \cdot Q(j)=0 \text {. }
$$

Normal coordinates are complex. You can go to the coordinates $q(j)$, which results in the Hamilton function being reduced to the form

$$
H=\frac{1}{2} \sum_{j}\left[p^{2}(j)+w^{2} q^{2}(j)\right],
$$

where $p(j)=\dot{q}(j)$ and the variables $p(j) q(j)$ and are real.

We pass to the quantum case, in which these quantities are considered as operators

$$
\hat{p}(j)=-i h \frac{\partial}{\partial q(j)} \hat{q}(j)=q(j) .
$$

In this case, the Schrodinger equation has the form

$$
\frac{1}{2} \sum_{j}\left\{-\hbar^{2} \frac{\partial}{\partial q(j)}+w^{2}(j) \cdot q^{2}(j)\right\} \psi=E \psi .
$$

The solution of equation (10) is well known and is written as

$$
\psi=\prod_{j} \psi_{m}(j) \cdot[q(j)],
$$

where is the vibrational quantum number of the oscillator with index $j$. Each of these functions satisfies the equation

$$
\left\{-\frac{\hbar^{2}}{2} \cdot \frac{\partial^{2}}{\partial q^{2}(j)}+\frac{1}{2} \cdot w^{2} \cdot q^{2}(j)\right\} \psi_{m}=E_{m} \cdot \psi_{m} .
$$

The total energy $E$ of a crystal in the state described by the numbers is

$$
E=\sum_{j} E_{m(j)} \text {. }
$$

Solutions of such an equation as (11) are well known [14]

$$
\psi_{m}(q)=\left(\frac{\beta}{\pi^{\frac{1}{2}} \cdot 2^{n} \cdot m}\right)^{1 / 2} \cdot \exp \left(-\frac{1}{2} \cdot \beta^{2} q^{2}\right) \cdot H_{m}(\beta q),
$$

where $\beta^{2}=\frac{1}{\hbar} \cdot w^{2}(j), H_{m}(x)$ is a Hermite polynomial of order $m$.

The corresponding energy levels are determined by the formula

$$
E_{m}=\left[m(j)+\frac{1}{2}\right] \cdot \hbar w(j) .
$$

Having determined a fairly General solution to this oscillatory problem, it is necessary to proceed to the consideration of Raman scattering of light on the discussed PSE. We introduce the intensity of light scattering in a single solid angle $I$, which is proportional to the transition probability:

$$
I_{\lambda \lambda \overline{\lambda \lambda^{\prime}}}=\sum_{n}\left(n \left(P _ { \lambda \lambda ^ { \prime } } \left(\overline { n } \left(\left(\overline { n } \left(P_{\overline{\lambda \bar{\lambda}^{\prime}}}(n) \cdot \delta\left(\Delta w-w_{n \bar{n}}\right) .\right.\right.\right.\right.\right.\right.
$$

Here $(n)=\left(\chi_{0 n}\left(\right.\right.$ are the initial and $\left(\bar{n}\left(=\chi_{0 \bar{n}}\right.\right.$ ( final vibrational States. Expression (13) corresponds to the case of a temperature equal to zero. To generalize to the case $T \neq 0$, we should include in (13) the temperature averaging over the initial States. Assuming further that the energy change during scattering is equal to $\Delta w$ is fixed, we write a generalized expression for the scattering tensor [15]:

$$
I_{\lambda \lambda \overline{\lambda \bar{\lambda}^{\prime}}}(\Delta w, T)=\frac{1}{Z} \sum_{n \bar{n}}\left(n \left(P _ { \lambda \lambda ^ { \prime } } \left(\overline { n } \left(\cdot \left(\overline { n } \left(P _ { \overline { \lambda \overline { \lambda } ^ { \prime } } } \left(n \left(\cdot e^{-\beta E_{n}} \cdot \delta\left(\Delta w-w_{n \bar{n}}\right),\right.\right.\right.\right.\right.\right.\right.\right.
$$

where $\beta=(k \cdot T)^{-1}, Z=\sum_{n} e^{-\beta E_{n}}$. 
Expression (14) can be represented in terms of the spectral density of the green temperature function by rewriting the matrix elements of the polarizability operator in the framework of secondary quantization. After that, the expression for intensity can be written using the green function or its Fourier components [15]. We can limit ourselves to a simple calculation of matrix elements with a known expression (12) for the wave function of oscillating PSE. Thus, knowing the matrix elements of the polarizability operator, it is easy to calculate the matrix elements of the form $\left(n\left(P_{\lambda \lambda^{\prime}}(\bar{n}\right.\right.$ ( and find values for the intensity of Raman scattering of light on the PSE for a specific vibrational transition.

In addition to this method of calculating the intensity of Raman scattering of light on structures, another method can be used, which is somewhat different from this [13]. By finding the equation of motion for the green function, one can obtain a system of linear non-uniform equations that is sufficiently easy to solve. This method allows you to calculate the elements of the series that the intensity is decomposed into.

Recently, it is common to refer aperiodic structures to structures that are in accordance with the Fibonacci series. We obtain solutions that allow us to judge the structure of any aperiodic lattice. In [13], we obtained a ratio for Raman scattering frequencies that corresponded to the numbers of the Fibonacci series. Intensity peaks were detected in the acoustic region with frequencies: $w_{1}=13.4, w_{2}=21.7, w_{3}=35.0$ and $w_{4}=56.7 \mathrm{~cm}^{-1}$. It is not difficult to notice that $w_{2} / w_{1}=w_{3} / w_{2}=w_{4} / w_{3}=\frac{\sqrt{5}+1}{2}$ is the number of the Golden section, that is, with some accuracy, the frequencies obtained both from the calculation and from the experiment are multiples of the corresponding Fibonacci numbers. The superatomic lattice of the studied sample was dimensionally quantized by the numbers of this series. The obtained result of this work gives grounds to assert that the vibrational Raman spectra represent direct information about the structure of the superatomic lattice.

\section{Conclusion}

Two methods for calculating the parameters of a block modulated lattice are considered. Despite the approximations, the methods allow us to reveal a qualitative picture of the electronic crystal in some cases, the theory and experiment give a satisfactory match. In other cases, such approximations are crude and insufficient to obtain accurate values of the spectral characteristics of a quantum-dimensional lattice. To get a more accurate picture, several significant amendments should be included in the consideration of both tasks. In the method based on the light absorption spectra of the BH structure, it is necessary to take into account the presence of wave functions outside the PSE. The symmetry of the PSE makes a significant contribution to the solution, and in the future it is possible to abandon the spherical symmetry of its potential. Taking these amendments into account is the next step in this task. In the method based on the vibrational Raman spectra of light by the microblock structure of the crystal, it is possible to further consider the 3-dimensional case. Currently, issues related to quantization of the crystal structure are widely considered. A significant interest is the study of the properties of such crystal lattices based on pre-known models of the crystal at a level other than the atomic one.

\section{References}

1 Бассани Ф. Электронные состояния и оптические переходы в твердых телах / Ф. Бассани, Дж. Пастори Парравичини. - М.: Наука, 1982. - 391 с.

2 Borodin Y.V. Research of nanocomposite structure of boron nitride at proton radiation / Y.V. Borodin, D.S. Ermolaev, V. Pak, K. Zhang // IOP Conference Series: Materials Science and Engineering. — 2016. — Vol. 110. — 4 p. DOI: 10.1088/1757$899 X / 110 / 1 / 012072$.

3 Tsu R. Passivation defects in polycrystalline superlattices and quantum well structures / R. Tsu, E.H. Nicollian, A. Reisman // Appl. Phys. Lett. — 1989. — Vol. 55, No. 18. - P. 1897-1899.

4 Borodin Y.V. The formation of nanocomposition structure in crystals / Y.V. Borodin and A.N. Sergeev // Proceedings of the 3rd International Forum on Strategic Technology, IFOST. - 2008. - P. 174-176.

5 Yurov V.M. Study of dimensional dependencies of thermodynamic characteristics of nanoparticles / V.M. Yurov, V.V. Arkhipov, G.A. Ranova, V.Ch. Laurinas // Bulletin of the University of Karaganda - Physics. — 2019. — No. 2(94). - P. 3541. DOI: $10.31489 / 2019 \mathrm{Ph} 2 / 35-41$.

6 Yurov V.M. Structural phase transition in surface layer of metals / V.M. Yurov, S.A. Guchenko, V.Ch. Laurinas, O.N. Zavatskaya // Bulletin of the University of Karaganda - Physics. - 2019. - No. 1(93). - P. 50-60. DOI 10.31489/2019Ph1/50-60. 
7 Vereshchagin, V.I. Boron nitride with packets of nanotubes for microcomposite ceramics / V.I. Vereshchagin, M.A. Sergeev, B.S. Semukhin, Yu.V. Borodin // Refractories and Industrial Ceramics. - 2000. - Vol. 41, No. 11-12. - P. 440-443.

8 Каули Дж. Физика дифракции / Дж. Каули. - М.: Мир, 1979. — 431 р.

9 Borodin Y.V. Low-temperature nanodoping of protonated $\mathrm{LiNbO}_{3}$ crystals by univalent ions / Y.V. Borodin // Technical Physics. — 2015. - Vol. 60. - P. 107-111.

10 Флюгге 3. Задачи по квантовой механике. - Т. 1/ 3. Флюгге. - М.: Мир, 1974. - 286 с.

11 Любарский Г.Я. Теория групп и ее применение в физике / Г.Я. Любарский. - М.: Наука, 1958. — 354 с.

12 Локтюшин А.А. Оптические спектры электронных центров окраски / А.А. Локтюшин. — Томск, 1983. — 9 с. Рукоп. деп. в ВИНИТИ 12 июля 1983 г., № 4328-83.

13 Wang Chumin. Theory of the Raman Response in Fibonacci Superlattices / Chumin Wang, R.A. Barrio // Phys. Rev. B. 1988. - Vol. 61. - P. 191.

14 Сущинский М.М. Спектры комбинационного рассеяния молекул и кристаллов / М.М. Сущинский. - М.: Наука, 1969. - $576 \mathrm{c}$.

15 Бирман Дж. Пространственная симметрия и оптические свойства твердых тел / Дж. Бирман. — М.: Наука, 1978. T. $2 .-352 \mathrm{c}$.

\author{
Ю.В. Бородин, К.В. Сысолов, В.Р. Ранде, Г.В. Вавилова, О. Стары
}

\title{
Наноөлшемді кристалды құрылымдық элементтердің спектроскопиясы
}

Құрылымдық элементтерді, нанобөлшектерді, микроблоктарды және басқа да наноөлшемді объектілерді зерттеу кристалдардың тепе-тең емес қасиеттерін зерттеудің маңызды бөлігі. Наноөлшемді құрылымдардың тәртібі қоспалау, деформация және сәулемен өзара әрекеттесуде кристалды торлардың динамикасын бағалауға мүмкіндік береді. Рентгендік және электронды-микроскопиялық зерттеулермен қатар наноөлшемді объектілердің өлшемдерін, олардың электрондарының энергиясын және электрондық күйдің симметриясын анықтаудың оптикалық әдістері кеңінен колданылады. Наноөлшемді объектілер арасында кристалдық құрылымның блоктық-иерархиялық (БИ) моделін әзірлеуге байланысты протон-бөлінген құрылымдық элементтер (ПҚЭ) ерекше назар аударады. Мақалада кванттық-өлшемдік құрылымдар моделіндегі ПҚЭ кристалдарының мөлшерін есептеу мүмкіндігі қарастырылған. Бұл модельге сәйкес, ПҚЭ-де кристалдар әлеуетінің мәндерінен басқа, жалпы қабылданған теориядан тыс жоғары электрондық тығыздық аймағын қарастыру керек. Эксперименталды деректер осы аймақтың жағдайын ПҚЭ атом ядросының айналасында оқшауландырылған деп анықтауға мүмкіндік береді. Атомдық қаңқа жалпы жағдайда элементарлық ұяшыққа сәйкес келеді, яғни атомдардың бір санынан тұрады және симметрияның бір нүктелі тобы бар.

Кілт сөздер: нанобөлшектер, микроблоктар, наноөлшемді құрылымдық элементтер, протондыбөлінген құрылымдық элементтер.

\section{Ю.В. Бородин, К.В. Сысолов, В.Р. Ранде, Г.В. Вавилова, О. Стары}

\section{Спектроскопия наноразмерных кристаллических структурных элементов}

\begin{abstract}
Изучение структурных элементов, наночастиц, микроблоков и других наноразмерных объектов было важной частью изучения неравновесных свойств кристаллов. Поведение наноразмерных структур позволяет судить о динамике кристаллической решетки при легировании, деформации и взаимодействии с излучением. Наряду с рентгеновскими и электронно-микроскопическими исследованиями все шире используются оптические методы определения размеров наноразмерных объектов, энергии их электронов и симметрии электронных состояний. Среди наноразмерных объектов особое внимание привлекают протонно-разделенные структурные элементы (ПСЭ) в связи с разработкой блочноиерархической $(\mathrm{BH})$ модели кристаллической структуры. В статье рассмотрена возможность расчета размеров кристаллов ПСЭ в модели квантово-размерных структур. Согласно этой модели, кроме значений потенциала кристалла в ПСЭ, следует изучить область высокой электронной плотности, существование которой выходит за рамки общепринятой теории. Экспериментальные данные позволяют определить положение этой зоны как локализованной вокруг атомного ядра ПСЭ. Заметим, что атомный остов в общем случае совпадает с элементарной ячейкой, то есть состоит из одного и того же числа атомов и имеет одну и ту же точечную группу симметрии.
\end{abstract}

Ключевые слова: наночастицы, микроблоки, наноразмерные структурные элементы, протонноразделенные структурные элементы. 


\section{References}

1 Bassani, F., \& Pastori Parravichini, Dzh. (1982). Elektronnye sostoianiia i opticheskie perekhody v tverdykh telakh [Electronic States and optical transitions in solids]. Moscow: Nauka [in Russian].

2 Borodin, Y.V., Ermolaev, D.S., Pak, V., \& Zhang, K. (2016). Research of nanocomposite structure of boron nitride at proton radiation. Proceedings from RTEP2016 IOP Conference Series: Materials Science and Engineering, 110, 1-4. DOI: 10.1088/1757$899 \mathrm{X} / 110 / 1 / 012072$.

3 Tsu, R., Nicollian, E.H., \& Reisman, A. (1989). Passivation defects in polycrystalline superlattices and quantum well structures. Appl. Phys. Lett., 55, 18, 1897-1899.

4 Borodin, Y.V., \& Sergeev, A.N. (2008). The formation of nanocomposition structure in crystals. Proceedings of the 3rd International Forum on Strategic Technology, IFOST, 174-176.

5 Yurov, V.M., Arkhipov, V.V., Ranova, G.A., \& Laurinas, V.Ch. (2019). Study of dimensional dependencies of thermodynamic characteristics of nanoparticles. Bulletin of the University of Karaganda - Physics, 2(94), 35-41. DOI: 10.31489/2019Ph2/3541.

6 Yurov, V.M., Guchenko, S.A., Laurinas, V.Ch., \& Zavatskaya, O.N. (2019). Structural phase transition in surface layer of metals. Bulletin of the University of Karaganda - Physics, 1(93), 50-60. DOI: 10.31489/2019Ph1/50-60.

7 Vereshchagin, V.I., Sergeev, M.A., Semukhin, B.S., \& Borodin, Y.V. (2000). Boron nitride with packets of nanotubes for microcomposite ceramics. Refractories and Industrial Ceramics, 41, 11-12, 440-443.

8 Kauli, Dzh. (1979). Fizika difraktsii [Physics of diffraction]. Moscow: Mir [in Russian].

9 Borodin, Y.V. (2015). Low-temperature nanodoping of protonated $\mathrm{LiNbO}_{3}$ crystals by univalent ions. Technical Physics, 60 , $107-111$.

10 Fliugge, Z. (1974). Zadachi po kvantovoi mekhanike [Problems in quantum mechanics]. Moscow: Mir [in Russian].

11 Liubarskii, H.Ya. (1958). Teoriia hrupp i ee primenenie $v$ fizike [Group theory and its application in physics]. Moscow: Nauka [in Russian].

12 Loktiushin, A.A. (1983). Opticheskie spektry elektronnykh tsentrov okraski [Optical spectra of electronic color centers]. Rukopis deponirovana v VINITI 12 iiulia 1983 h., № 4328-83 - Manuscript deposited at VINITI, July, 12, 1983, No. 4328-83. Tomsk [in Russian].

13 Wang, Chumin, \& Barrio, R.A. (1988). Theory of the Raman Response in Fibonacci Superlattices. Phys. Rev. B., 61, 191.

14 Sushchinskii, M.M. (1969). Spektry kombinatsionnoho rasseianiia molekul i kristallov [Spectra of Raman scattering of molecules and crystals]. Moscow: Nauka [in Russian].

15 Birman, Dzh. (1978). Prostranstvennaia simmetriia i opticheskie svoistva tverdykh tel [Spatial symmetry and optical properties of solids]. Vol. 2. Moscow: Nauka [in Russian]. 